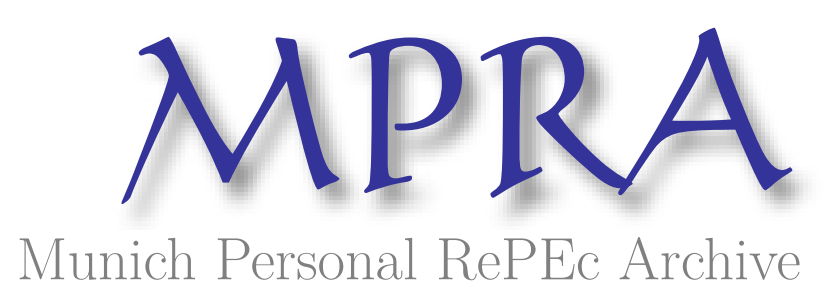

\title{
Government and Governance of Regional Triple Helix Interactions
}

Danson, Michael and Todeva, Emanuela

Heriot Watt University, BCNED

2016

Online at https://mpra.ub.uni-muenchen.de/76780/

MPRA Paper No. 76780, posted 15 Feb 2017 12:05 UTC 


\section{Government and Governance of Regional Triple Helix Interactions}

Mike Danson \& Emanuela Todeva ${ }^{1}$

\section{Abstract:}

This conceptual paper contributes to the discussion on the role of regional government and regional triple helix constellations driving economic development and growth within regional boundaries. We investigate the impact of regionalism and subsidiarity on regional triple helix constellations and the questions of governmentality, governance and institutional development at regional level. We put emphasis on the fact that the position of regional authorities in the structure of government and policy boundaries are best implemented at a regional level (the principles of regionalism and subsidiarity), and that localised policy practices represent a more precise view on the government-industryuniversity interactions (the principle of governmentality). We look at the regional triple helix context as a prerequisite for stakeholder engagement, enhancing innovation capabilities and entrepreneurial behaviour. The paper identifies the drivers behind regional competitiveness and economic development, and investigates the positive externalities from strong triple helix constellations, as well as the impact of government support and institutionalised cooperation on value creation and value capture at the level of the locale. The paper offers a stylised model (Fig. 1) of the conditions for value creation and value capture and offers a critical overview of the debates around the rationale for regional governments. Examples are drawn from Scotland, England and some comparable parts of Europe.

Keywords: regional development agencies; triple helix; regional governance; public policy; regional economic development

\section{An introduction to regions and development within boundaries}

This paper explores the theoretical background for interventions at the regional level according to defined macroeconomic objectives and policy aims. We discuss the rationale for localised governance and specific institutional arrangements at the regional level. We look at the evolution of Triple Helix interactions between the private sector, the regional public authorities and the universities and college education providers, shaping the regional impact from policy implementation.

Our previous research has argued that decisions on allocating public resources and policy implementation practices pose significant challenge for areas of jurisdiction that are relatively peripheral to major metropolitan concentrations of economic power and activities, such as the

\footnotetext{
${ }^{1}$ Danson, M. and Todeva, E. (2016) 'Government and Governance of Regional Triple Helix Interactions', Industry and Higher Education,30 (1): 13-26, DOI:10.5367/ihe.2016.0293.
} 
landward regions of Scotland, Norway and Sweden (Danson and de Souza, 2012). Regional agricultural and land-based economies have natural geographic boundaries that include sparsely populated areas, fragmented services, and rural communities, and for many of these there are strong arguments for trying to balance the benefits of extra-regional connections with solutions that do not further disadvantage and exacerbate isolation and limited market size. These challenges are contrasted with the inner-city questions that cut across a broad regional geography of decreasing or relatively prosperous regional economies (see for example Syrett, 2011, for an exploration of these themes in London). Many inner cities are underperforming across a range of social and economic indicators that call for government intervention (Syrett, 2011), although they are subject to agglomeration economies of scale and scope (Krugman, 1991). Underdevelopment and underperformance are two cases for government intervention, when it is accepted that without a regeneration effort and investment, the localised market failure cannot be remedied by itself.

Further, in rural areas the region should be considered as the most appropriate jurisdiction level for the delivery of certain policies, such as and especially in the areas of R\&D, technology and innovation (CEC, 2014; Hewitt-Dundas and Roper, 2011). The case for regional policy intervention justifies the need for specific organisations and institutions to operate at a subnational scale (Armstrong, 1997; King, 1984). It follows that the region offers a mezzo-level focus for these functions and interventions of government in order to minimise the effect of market failure and to optimise the opportunities offered by public investment. At the regional level, public authorities can secure economies of scale, scope and co-location in policy implementation and can enable a bottom-up approach (Halkier and Danson, 1997; Danson and Lloyd, 2012) to capturing localised positive externalities (Cooke and Morgan, 1998).

The aim of this paper is to review the theoretical implications of the notion that regions represent an appropriate level to arrange collaborations and to promote innovations. Following from this, it is proposed that the scope of intervention is focused at the middle level government authority. The paper therefore seeks to address the questions of: a) identifying the drivers behind regional economic development; b) positioning regional authorities in the structure of government responsible for the implementation of innovation policies for growth; and, c) analysing the role and impact of localised institutions and triple helix governance and government support on regional capabilities for growth. In the subsequent parts of this paper we outline the theoretical foundations of governance and governmentality ${ }^{2}$ in order to explain the role that regional authorities play in this process. Then we

\footnotetext{
${ }^{2}$ Governmentality is applied here as the organized practices of governments and includes in particular the 'art of government' and 'governmental rationality' (Gordon, 1991), the 'how' of
} 
focus on the recent history of the regional authorities in the UK and the drivers for enhancement of local capabilities, among which are universities. We interrogate the Triple Helix model and its application at regional level or the ability of regional governments, local businesses and universities to generate a positive dynamic for sustainable growth. Finally, we analyse different approaches and forms of intervention that are undertaken in the UK with a critical discussion of the relatively more recent evolution of Scottish Enterprise - the Scottish regional development agency (RDA) - and economic development interventions, compared with Oxfordshire region, where the RDA was abolished in 2010. Conclusions and recommendations are made as to how regional triple helix constellations are strengthened by the universities raising their local profile while pursuing internationalisation and global visibility. The contrasting cases of South Oxfordshire and Scotland reveal that effective triple helix constellations depend both on how universities blend with the regional institutional landscape, and the existence of regional authorities as a coordination agency. The next section discusses the nature and sources of governmentality at national and sub-national level.

\section{Government and governance of the economic development process}

Governance is a system / mechanism for allocation of resources, and for exercising control and coordination of economic activities that facilitate strategic direction, accountability, transparency and wealth creation (Todeva, 2013). Economic growth, productivity and efficiency are all seen as deriving from this wealth creation, and in the context of increasing global connectivity and transparency through the advancement of the internet technology, ICT and communications. These processes and technologies affect governmentality beyond the notion of e-government and equal access. Governance encompasses particular institutional forms that facilitate value creation and localised capturing of value.

There is a shared view across many theoretical perspectives that public governance involves simultaneously: a) governance of the society and economy; b) institutionalisation of justice in the public domain; and, c) management of the resource allocation process through institutionalisation of incentives and constraints (Wamsley, 1990, pp. 21-29). The main challenges to public governance are: to engage with these activities and functions while keeping accountability of the agents and institutions, their legitimacy, and counteracting design flaws in the governance principles and procedures (Koppell, 2010).

governing (Jeffreys and Sigley, 2009), and the techniques, strategies and most reasoned way of governing (Lemke, 2002; Foucault, 2008). 
Regulation and governance performed by the state imply fraud prevention, protection against opportunistic behaviour, the establishment of rules, actions that can mitigate risks from future failures, or financing and supervision over resource utilisation (Corder, 2009). All of these activities and functions are considered to be most effectively performed at national level and supported by national institutional arrangements, where regional and local representations do not have a remit to differentiate.

The economics of governance paradigm postulates that the regulation of a socio-economic system requires a legitimate government that has authority and powers, as well as the capacity and capabilities, to generate the rules that govern economic behaviour within the system of their jurisdiction. National / federal authorities hence have the power and legitimacy to make allocative decisions and implement policies, where regional authorities constitute hierarchically subordinate arms of power.

The economics of 'good' governance, however, have embraced the challenge for an 'ethical' code of practice beyond accountability. These are some universal principles such as fairness, justice, or transcendental publicity that require governments to absorb a moral position vis-à-vis the governed (Kant, 1785). Governmentality, hence, refers to effective and morally-just actions through transparent institutions and open consultation with stakeholders. Regional triple helix constellations bear the brunt of achieving effective, fair and just allocative decisions.

There are two diversions from this mainstream argumentation on governance. One is related to the notion of global governance and the cultural and political implications of the world being represented by a heterogeneous system of players among which are national law-makers, national law-followers, international law-followers, and unequal distribution of power among these agents. The second is the regional dimension, where complex socio-economic realities emerge out of localised interactions between economic actors and demand more particularistic solutions - again implemented by legitimate and empowered arms and branches of government.

The plurality of socio-economic contexts and governing arrangements at regional and national level stems from different social histories and memories (path dependence), from different levels of industrialisation, economic development, and different degree of liberalisation of the market forces (economic determinism), and from different political ideologies and cultural frameworks (political determinism) (Todeva, 2010). The social and political sciences have not been able so far to distil universal principles that establish the perfect moral order across all modalities of governance, or levels of power. 
Although citizens of autonomous states could choose an endless variety of laws and moral principles to govern their affairs, allocative decisions about scarce resources require a unifying authority with a unique capacity of power, where political direction and transcendental justice and fairness are embodied in institutionally organised decisions and actions at local sub-national and supra-national level (Kant, 1785).

The argument in this paper is that governments and regional authorities as regulators of socioeconomic systems and localised institutional environments are strategic actors in their capacity to actively shape economic behaviour, implementing various policies that facilitate economic interactions. Hence, there is a strong asymmetry between those making the law and those following it (Todeva, 2010). Regional and local authorities as extensions to the national level of government shorten the distance between decision making and implementation, and as such they facilitate the stakeholder consultation part of the policy process. Regional authorities enhance both the value creation and the value capture at the level of the locale. The level of agglomeration of geographic areas, however, is arbitrary, and multiple levels of government intermediation (i.e. regional vs. local, vs. community-based authorities) are not necessarily guarantees for effective decision making, or for efficient implementation process. The direction of the regional effects on the triple helix constellations is visualised on Fig. 1. The next section of the paper looks at different mechanisms that enhance the value added by regional authorities, which offsets the costs of administration.

\section{The rationale for regional authorities and mezzo level public administration}

Authoritative allocation of resources is central to human society (Musgrave, 1959; Newlands, 1997; Russell and Waste, 1998). The costs of the public administration process, however, can vary according to different implementation regimes, where different regulatory mechanisms and governance forms are adopted. Administrative costs can accumulate from: the efforts to negotiate and take political decisions; the monitoring and control of policy implementation; the costs of termination of policies; the costs of institution building and support; and the general costs of administration and management (Frantz, 1997, Greenwood, 1997). Rational agents in this context are those that can calculate and minimise these costs - motives that carry no ethical value and, hence, no distributive justice. At the same time, when evident increase of costs is identified, the best authority to undertake a cost-benefit analysis are the regional authorities, who stand in-between the spending local authorities and the grant giving national authority (CEC, 2014). Intermediation in governance is rarely recognised for its value added through coordination and supervision (Fig. 1).

Implementing politically motivated administrative reforms, market oriented or otherwise, is not neutral. Changing the rules of the game by governments changes the probable winners and losers in 
political contests, and pre-determines who would be disenfranchised in this process (Knott and Miller, 1987; Russell and Waste, 1998). Regional governments, therefore, are constituted to minimise the number and scale of disenfranchised local citizens. Governments are the managers of a reform process, and their political choices pre-select the outcomes for all. Minimising the negative impact of policies hence is another source of value added. Devolution to the Scottish Parliament in 1999 was partly in response to the demand for democratic accountability over economic development powers that had been the administrative responsibility of UK government departments, QUANGOs and other non-departmental bodies. Synergies, coherence and efficiencies were expected to complement this move of government and governance closer to the actors within Scotland (Newlands, 1997; Danson and Lloyd, 2012).

The distinction between 'principals and agents', and between 'governors and governed' is among the questions of governance that open a wide schism of rights, influence, and domination, where the conflict of interests frames an endless contest between different groups of actors (Todeva, 2010). Regional authorities therefore are at the crossroads of a complex political process that arises when resource allocation takes place. Multiple layers of government may obscure the process of resource allocation when efficiencies are pursued, but can add value when market failures are addressed at a localised level, which offsets the overall costs.

From an institutional point of view it is difficult to discriminate clearly the distinction between leading institutions that represent the foundations of government, or agencies engaged in distributive decision making and resource allocation at the regional level, and other institutional stakeholders that influence the policy process and support the implementation of distributive decisions. A discriminatory principle that can be used to categorise institutions at a regional level is whether they perform a utility function, or a normative (regulatory) function. Specific normative questions that can be asked at a regional level are: the clear definition of the public interest, and the role prescribed to and played by the public agencies in the governance process (Todeva, 2010). While the normative questions are related to political choices, the utility questions derive from the implementation process, and focus on the actual working of government. In the practice of economic development, this separation of utility and normative is demonstrated in some of the rationales for arms-length RDAs, as discussed below.

All functions and operations of regional public authorities have both utility (practice) and normative (rules) aspects. There is uncritical acceptance of decisions as morally neutral and empirically selfevident. This is due to the essentially technicist idea of organizational analysis that decisions are divorced from the moral questions of the 'good'. Decision-based analysis is usually trivialized, and questions of power and influence are neglected altogether (Harmon, 1998). This applies not only to 
generalised political decisions regarding the establishment of fundamental co-ordination mechanisms, but to specific administrative decisions on allocation of resources at the regional level. Moral and ethical considerations on the distribution of outcomes to community and society at large are substituted with arguments for cost-efficiency (Todeva, 2010). Regional authorities (or national, for that matter) are exempt from being judged for their moral and ethical foundations, where the economic rationale for governance dominates observations.

Decisions involve distribution of resources, which are material in nature and are unequally accessible in a society. Distribution of resources in heterogeneous systems of unequal human agents involves judgements on human needs and intellectual capabilities, assessment of value, and the use of preferences to overcome resource constraints. Administrative decisions involve negotiations and a subsequent administrative control, and hence are in the realm of realities and praxis, rather than in the realm of a priori knowledge and judgement. The translation of a priori knowledge and moral judgement to institutional practice is obscured by agency interests and capacity, organisational procedures and legacies, or the acting and choices of human agents in power. Decisions by public authorities cannot be divorced from the process of decision-making, where interests are recognised, motives are enacted, and outcomes are negotiated. We can put a clear distinction between those that make the decisions (law-makers), and those that are subjected to the redistributive impact from these decisions (law-followers) (Todeva, 2010). Regional authorities as such (Fig. 1) enhance the capacity of law-makers, but do not guarantee either the fairness of the law, or the effectiveness of the rules and procedures developed at sub-national level. However, they provide a narrow definition of the localised stakeholders.

Figure 1: Regional Triple Helix Constellations
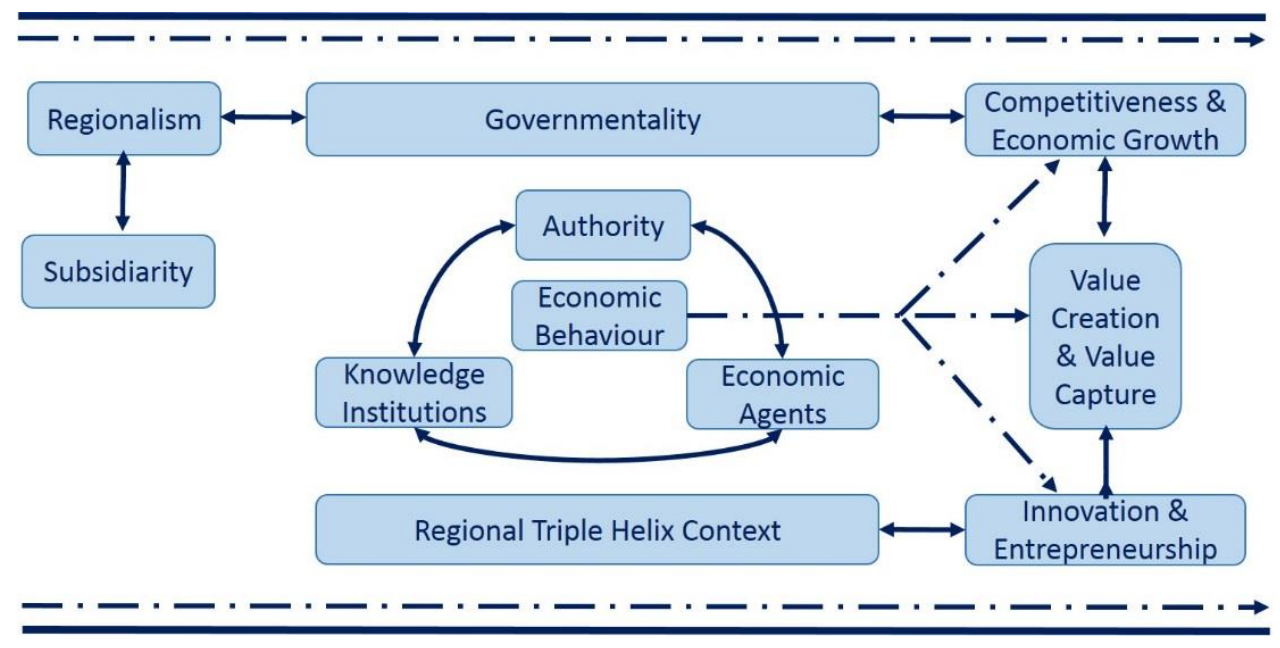

Source: Authors' own. 
The legitimacy of the decision-making authority and the administrative capabilities of government officials to enact decisions are of critical importance. Under-resourced regional governments, hence, could be lacking both administrative capacity and political legitimacy, which could undermine their operations and impact (Todeva, 2010). The rationale for regional government authority can be undermined or enhanced by the administrative capacity and dynamic capabilities of local agents and institutions.

\section{The rationale for regional government support}

The concept of governmentality, discussed in the previous section, employs a very broad definition of the role of government among which is the responsibility for a morally just allocation of resources, while counteracting market failure. Active engagement by government in economic management on the grounds of stabilisation, distribution, allocation, and growth, has been discussed extensively in the governance and economic policy literature (Musgrave, 1959). Macroeconomic stabilisation policy functions of government are held to be most effectively and efficiently delivered at the highest administrative level possible, or at the level of the nation-state (e.g. the UK Westminster government). In the geographical hierarchy of vertically integrated governments, allocation and growth objectives are promoted as more effectively and efficiently delivered at the national and sub-national state levels by regional and sub-regional authorities (e.g. the Scottish Government and local authorities) (Newlands, 1997).

There is a rationale for intervention by governments to increase and improve economic efficiency (Newlands, 1997; Keating, 2006). In cases of absence of an alternative market solution, the needs of actors for land, labour, capital, technology and entrepreneurship, and for the optimal allocation of society's resources, coupled with the societal need for innovation and upgrade of skills and capabilities increases the demand for local coordination of supply. Regional innovation and economic development policies provide a localised framework of incentives for local industry-universities and other public sector innovation actors (as promoted by the European Commission (CEC, 2014)). Regional triple helix constellations hence become essential for the delivery of such policies (Fig. 1).

Yet, the triple helix literature rarely recognises the role of regional environments and institutional arrangements that exhibit the selection choices of regional and local authorities and innovation actors. The establishment of a regional policy framework is consistent with broader social democratic political thinking which served in the early post-war period to influence the specific forms of state intervention (Giddens, 1997). The evolving development of regional authorities has enabled governments to secure a greater integrated policy focus in order to secure network gains in public administration and more 
effective joint working with the private sector (Lloyd, 2008). This focus on a localised metropolitan or (sub-)regional dimension coincides also with the neoliberal economic agenda where regeneration through public - private partnerships is entangled with land and property development schemes to secure economic recovery, investment, and employment. Examples of such localised policy solutions are the Enterprise Zones (Lloyd, 2008; Lloyd and Danson, 1991) and the Urban Development Corporations (Deakin and Edwards, 1993; Danson and Lloyd, 2012). These localised models assume regular supply of skills from local or distant education providers and do not see the universities as major players in the policy process.

A regional policy institutional framework based on defined incentives, disincentives, and interventions has been promoted nationally over a long period (Armstrong, 1997; Armstrong and Taylor, 2000; HM Treasury, 2001, 2007) and within the European Union (CEC, 2014) to achieve convergence in relative regional economic activity whilst contributing to national economic objectives. Policies and actions at the regional level in this context offer the potential for enabling more strategic thinking and consistency in public and private decision making at the appropriate scales (Regional Policy Commission, 1996; Danson and Lloyd, 2012). Increasingly, regionalism ${ }^{3}$ also feeds into the neo-liberal agenda for achieving geographical competitiveness and sustainable economic growth and development (Danson and Lloyd, 2012; Bailey et al., 2010).

For the last quarter of a century, the pursuit of 'competitiveness' has come to dominate the macroeconomic strategy and policy domains (CEC, 1994; HM Treasury, 2001; Danson and Lloyd, 2012). This is complementary to the regionalism agenda as it promotes the idea of endogenous growth through competition between nations and regions. In good times and bad, however, there has also been a recognition that for this to be sustainable economic growth it must also be inclusive. Indeed, the Cecchini Report (Cecchini, 1988) on the completion of the single market identified this as a prerequisite and as an elementary pillar in a successful European Union. Since then, various treaties and interventions have promoted this twin approach of regional economic development institutions and strategic interventions, pursuing economic strategy based on the dual aims of 'competitiveness and inclusion' (Fig. 1). In the example of Scotland, which maintains its RDA, pursuing the twin objectives, sustainable development is understood essentially to involve the community across all dimensions of the economy, society and the environment and to being accepted across all social partners - trade unions, small and medium enterprises (SMEs), community, and voluntary sectors (Danson et al., 2012; Danson and Lloyd, 2012). This can be seen to contrast with the experiences of the RDAs in England

\footnotetext{
${ }^{3}$ The theory or practice of regional rather than central systems of administration or economic, cultural, or political affiliation.
} 
before their abolition, with their lack of democratic control through directly elected regional authorities (Bailey et al., 2010).

These steps to encourage the movement and consolidation of powers to the regional level were supported by the parallel and complementary promotion of the concept of 'subsidiarity' (taking and delivering policies at the most appropriate jurisdictional level as defined by Armstrong (1997). Creating an environment and platform at the sub-national level where key players can interact more effectively has been on various agenda for a few decades, and longer in some territories (Halkier and Danson, 1997; Halkier, 2006; Danson and Lloyd, 2012). Within this context, the 'local' level appears as the most efficient for the development and delivery of a number of functions for SME support (for instance, in Scotland this is the responsibility of local government authorities through local Business Gateways) for occupational training, or other regional or innovation policies (Halkier and Danson, 1997; Danson and Lloyd, 2012). Generally, the rationale for empowering regional authorities supports the establishment of specific forms of organisations and policy instruments, which in the recent history in the UK are the Regional Development Agencies (RDAs), and more specifically, Scottish Enterprise (Danson and Lloyd, 2012).

A model RDA is defined as being in a semi-autonomous position vis-à-vis its sponsoring political authority, supporting mainly indigenous firms by means of 'soft' policy instruments (Halkier and Danson, 1997, p245). It is a multifunctional and integrated agency, the level of which may be determined by the range of policy instruments it uses. Consistent with the thrust of the growth model described above, RDAs are associated with promoting 'bottom-up' development and realising endogenous potential (Stöhr, 1989). Such a bottom-up approach is in contrast to the more conventional, traditional top-down regional policy arrangements characterised as relatively dirigiste (Cooke and Morgan, 1998). The deliberate spatial dimension to economic development incorporates the provision of regional incentives and other forms of infrastructure for innovative firms and universities, and generally the RDAs provide a complementarity, and reciprocity, with the national regional policy framework. As RDAs work "outside the mainstream government" arguably they are better placed to facilitate the pursuit of public policies without direct government intervention making the development agency approach to regional economic development relatively more acceptable to the full range of social partners, without necessarily undermining accountability and legitimacy considerations (Halkier and Danson, 1997, p243). RDAs, hence, are designed as focal triple helix actors without a reference to the triple helix model, or the national innovation priorities and targets.

RDAs are now ubiquitous as a key institution for delivering regional economic development across Europe, with the notable exception of the position in England (Danson et al., 2012; Bailey et al., 2010). European Union regulations and implementation strategies (see CEC, 2014) have similarly led to a 
degree of uniformity across the EU in the landscape of governance, infrastructure, and innovation systems so that the concept and practice of the triple helix model have become embedded into the current round of ERDF and ESF regional development programmes (CEC, 2015).

In the regional milieux of economic actors, the localised supply of skills and innovation capabilities is assumed, and regional governments shape the environment for regional economic development and innovation (Fig. 1). There are operational and resource relationships between local / regional / national government, local / regional /national agencies, universities and research institutions, as well as private sector businesses and community-based organisations. Collectively or otherwise, as described in the case study areas in Slovenia and Sweden, for example (Danson et al., 2012), these players create an institutional framework for the specific purpose of designing, developing and delivering a triple helix approach to addressing the management of these territorial spaces (Morgan, 2007). Forming a crucible for the research, development, innovation and commercialisation of concepts, products and processes being generated by universities and other laboratories therefore has become an essential priority of programmes within regional, national and European strategies (Asheim et al., 2003; Klofsten et al., 2015).

Across the EU, there has been a maturing convergence in national and regional administrative and institutional frameworks overall, within the context of diversity in economic conditions and regional economies, becoming more complex in structural terms. As regionalism (Fig. 1) leads to geographical imbalances in economic and industrial activity becoming more evident, so the European Union and national players have recognised and pursued strategies to realise potential at sub-national levels (CEC, 2014; Lawton Smith and Waters, 2015; Nozawa, 2015). Particularly with regard to research, development and technology innovations, at the core of the triple helix concept, there are concerns over the relationship between geographic imbalances and the capacity of regional authorities to address these through endogenous developments, as Hewitt-Dundas and Roper (2011) have explored for peripheral regions with a particular focus on Scotland and Ireland informing their analyses. As trade, investment, knowledge and technology flows are global in nature in the areas of smart specialisation and higher technologies especially (Cooke, 1995; Asheim et al., 2003), and there may be instances of plants being attracted to benefit from some localised endowments, non-core regions will struggle to compete (see Danson and de Souza, 2012, for assessment of the position across the northern periphery of Europe). The 'branch plant' problem of the $1970 \mathrm{~s}$ and 80 s explored the lack of higher order functions, powers and R\&D facilities inherent in much of the inward investment introduced to the 'regions' across the UK (Armstrong and Taylor, 2000; Harris and Thomas, 2009) and Ireland (O'Leary, 2015). As the staff and resources of the research institutions located in the 'problem regions' outwith the metropolitan core are still strongly oriented to their national and international 
discipline bases, the challenges of creating meaningful clusters and networks regionally are exacerbated (Bergum, 2012; Lindegaard, 2012). The closure of the local science and development laboratories in Scotland of the nationalised steel, coal and shipbuilding industries in the first half of the 1980s disrupted the capacity of these basic sectors to pursue innovations and developments appropriate to the regional industrial complex. So, regional partnerships and helixes that exercise concerted efforts to enhance location advantages and attract investment may be unable to deliver the positive outcomes anticipated by competitiveness strategies based on R\&D and innovation if key elements of the sector are absent.

The efficiency of governments both at regional and national level is measured by the extent of achievement of the policy objectives, compared to the costs of policy implementation (including monitoring and control) - whether it is related to market regulation, or to direct intervention in the economy. This evaluation does not consider the moral grounds for these policy objectives. The implementation of policy objectives involves not only allocation of resources, but building coalitions of agencies that bargain and negotiate between themselves over certain outcomes. The political authority that shapes the regulatory environment which subsequently affects individual and organisational behaviour is the leading agency of change and reform in a society. The level of this authority within the hierarchy of government can be determined uniquely for individual policy initiatives. The scope for triple helix interactions, hence, can vary.

Political objectives, institutional constraints, and individual motivations seem to be intertwined into a tight node that drives the continuous policy process. In this context, the social contract between the government and the public implicitly requires the support of an appropriate institutional framework, political leadership, and widely spread legitimacy of the administrative agencies (Todeva, 2010). In this environment, both regional and national authorities may have an issue with their reputation and output activities.

Regarding the issue of government intervention, behaviourism appears as complementary to institutionalism, as both explain how institutional constructs that produce social norms and subsequent behaviours (Russell and Waste, 1998) are simultaneously embedded at a national and at a regional level of authority. Institutions are necessary to change and maintain certain value preferences. However, these preferences, motivations and commitments are very often a subjective outcome of a cultural process of interpersonal interactions and a policy process of negotiations and bargaining, or what Kant refers to as imperfect reasons (1875). In this way, the Triple Helix model refers to a 'culture-specific phenomena', or culturally and institutionally embedded interactions. Neither behaviourism nor institutionalism have developed definitions of preferences and choices that represent perfect intentions, or prescriptions for the focus of regional vs. national. In fact, individual 
preferences and choices are defined as imperfect motivations in a Kantian sense, or humans pursuing the satisfaction of their individual interests (Todeva, 2010). As such, the stakeholder approach coaligns the individual with the institutional, where regional/ national boundaries become an issue of practice, rather than an issue of norm and legislative power. The triple helix literature does not address questions of levels of government and subsidiarity, or the regionalism in national innovation systems. The triple helix model is not particularly interested in the questions of innovation for competitiveness. The governmentality issue is addressed as the perpetual cycles of interactions across the helices, ignoring the imbalances of power, or the variations in the level of authority, subordination, or who bears the costs of triple helix interactions. The triple helix, however, as an heuristic tool, outlines the principles for identifying regional stakeholders.

Stakeholder engagement for economic development ultimately brings the challenge of public-private interactions, building innovation and support systems, and facilitation of sustainable investment flows. The triple helix model calls for stakeholder engagement and interactions in a productive capacity, and, from the establishment of the multi-agency, multi-annual and multi-functional GEAR (Glasgow Eastern Area Renewal) project, through area initiatives to the Strathclyde Regional Partnership, the building of a consensual approach to the strategic generation and delivery of economic development programmes in the region and Scotland was based on an inclusive approach to stakeholder involvement (Danson et al., 1999).

\section{Stakeholders and harnessing the triple helix interactions at regional level}

The Triple Helix as a concept is recognised to have a transformative effect on industry performance, generating accelerated knowledge and technology transfer between the public and the private sectors and inducing systemic change at regional, national and global levels (Etzkowitz and Ranga, 2010). In recent years we have observed a radical shift in the approach of governments - as active orchestrators of triple helix relationships, pursuing economic development through innovation and cluster policies; implementing institutional changes through community and participative practices; and influencing industry transformations through collaborative public-private funding, R\&D procurement, stimulating university - industry interactions and the co-location of technology firms within specific regional boundaries alongside supply chain upgrade (Bailey et al., 2010; Danson and Lloyd, 2012; Benneworth et al., 2015). The establishment of key sector fora and initiatives focused in particular locations across Scotland reflects such a strategic approach (Scottish Government, 2015), with local world-leading universities also encouraged and enabled to participate in wider collaborations such as UK Catapult Centres, Horizon 2020 and open innovation schemes (Kerry and Danson, this volume). The inclusion of universities and branch plants which are also active in global networks facilitates knowledge 
transfer into the regional economy, reinforcing the positive potential of the triple helix to deliver wider and deeper benefits to all local stakeholders.

As demonstrated in the literature and policy and strategy documents at national and European levels cited above, the triple helix model is expected to enable mapping of complex stakeholder interactions and to explain the positive development effects of collaboration between the public and the private sector. Unfortunately, regarding sub-national governance this economic approach to cooperation is underdeveloped in addressing the issues of investment, co-financing for innovation, or the interactions and transaction costs and their impact on competitiveness (Fig. 1). The regional vs. national level of innovation system performance is an essential question to address when identifying the lead triple helix actors. Co-financing and triple helix participation, driving innovation and growth can take place at different levels of government / industry, as well as across levels.

Regional innovation systems (RIS) are perceived as building blocks for national innovation systems (NIS), where all interrelated institutional actors that create, diffuse and exploit innovation within a region are mobilised by specific political objectives. More narrowly, these are local private sector R\&D departments, universities, public institutes and research laboratories that search and explore technological innovations and leverage their knowledge and capabilities for regional growth (Chung, 2002). The essence of RIS is the bundle of user-producer relationships that are embedded in localised industrial competitiveness and national regulatory frameworks, and resemble interactions and flow of resources, including labour, capital and knowledge mobility. A regional approach is more effective to formulate and implement, as the leading actors within the triple helix are more clearly interdependent and co-aligned for collaboration (Chung, 2002).

The regional focus for innovation is promoted also by the idea that innovation is context specific, and hence, regional context is more easy and appropriate to capture and assimilate (Doloreux, et.al., 2005). The concept of 'contextual innovation' is based on the assumption that innovative activity of firms is based to a large degree on localized resources such as a specialized labour market, subcontractor and supplier systems, local learning processes and spill-over effects, local traditions for cooperative and entrepreneurial attitudes, local supporting agencies and organizations, and the physical presence of customers and users (Cooke, 2001, Tödtling \& Kaufmann, 2001, Asheim, et.al., 2003).

The literature acknowledges that innovation occurs more easily in situations of geographic concentration and proximity, where regional clusters play a crucial role and regional authorities intervene with more impact (Danson et al., 1990; Doloreux, et.al., 2005). Regional triple helix actors and regional stakeholders hence hold a leading position in building social relationships that frame the 
activities of production, consumption and exchange. This is supported by substantial evidence of strong regional correlations between regional science-based outputs and GDP, or industry competitiveness (Lewison, 1991, Huggins, 2003, Howells, 2005). The literature goes further and identifies five types of institutionalised stakeholders that play a role as regional brokers and intermediaries - associative, behavioural, cognitive, regulative and consultative (Doloreux et.al., 2005). These institutions shape all regional triple helix actors and, hence, determine the dynamics within the regional triple helix. The impact of the regional institutional context (Fig. 1) can be measured in terms of governance, control, facilitation and optimisation in multi-lateral collaborations at a regional level and the practice of engagement in the transfer of knowledge and technology across the industry-university-government interface.

Regional triple helix constellations exhibit specific collaborative capacity and business models for cooperation in regions, and stakeholder engagement in decisions and sustainable solutions. There are already observations in the literature that investigate both the policy mixes and implementation at the regional level, particularly for regional smart specialisation, and the institutional and triple helix dynamics during the policy design and implementation stages (Nauwelaers et al., 2014; Benneworth, et.al., 2015).

The synergies in the regional triple helix emerge when entrepreneurialism becomes a norm embedded in the culture, invisibly guiding actors to collaborate. Territorial cohesion therefore emerges out of smart and localised policy interventions that deliver 'coordination at a distance' (Benneworth, et.al., 2015).

Universities among the localised triple helix actors are both subject to transformation regimes and act as a source of transforming practices, such as converting occasional entrepreneurial activities into regular behaviours, and ultimately into regional landmarks. The transformation of the status of universities in their urban and regional context creates significant impacts in terms of knowledgecreating, relationship-building, cultural development and economic growth (Anselin, et.al., 1997, Bottazzi and Petri, 2003, Breschi and Lissoni, 2009, Lazzeroni and Piccaluga, 2015). The challenge identified in this context is that the universities produce globally-mobile elites that intensify both inward and outward flows of knowledge, ideas, and capital (Swyngedouw, 1992).

Without a triple helix mode of coalitions and stakeholder leadership at a regional level, policy interventions remain fragmented and one-off initiatives without creating synergies for propitious innovation (Benneworth, et.al., 2015). It is acknowledged that pre-existing linkages between local industry and university encourages entrepreneurship, and entrepreneurial behaviour builds new and enhances the old links, transforming the regional public-private interface into a collaborative platform 
for knowledge flows (Lee, et.al., 2015). The approach in Scotland has evolved through broadly-based area initiatives to clusters to Intermediate Technology Institutes and key sector enterprise areas, not all have been successful but the underpinning principles of inclusion and partnership working are consistent with the good practice of triple helix models (Danson and Lloyd, 2012). Such regional dynamics represent a healthy regional cluster environment, encouraging new market entries as well as growth. The optimisation and orchestration of the triple helix interactions, however, is essential for the efficient management of costs and benefits.

Analytical dissection of clusters based around small urban areas reveals that the universities represent sometimes the largest employer in the region, and present a gateway for the internationalisation of regional outputs. The universities, however, are governed by a specific administrative authority, which poses a question of the level of value capture and impact (Fig. 1) (Lazzeroni and Piccaluga, 2015).

In the same way as universities are centres of innovation and knowledge, regional authorities are anchors for governing the innovation context, stirring collaboration across the university-industry interface and generating synergies across institutional boundaries. Regional triple helix spaces induce visibility and support for the creation of strong regional identities.

It is acknowledged, however, that the driver for public-initiated growth often remains national government funding for innovation, which represents implementation of the national policy agenda that produces strong regional effects. More critical observations of this mechanism acknowledge that such an approach is associated with significant inefficiencies in the allocation of funds with often disappointing (Lawton Smith and Waters, 2015) and uneven development (Bailey et al., 2010; Bergum, 2012; Cooke, 2001) results. An example of this is discussed in the Science Vale UK project by two UK counties (South Oxfordshire and Vale of White Horse), where entrepreneurial vision from the regional governing authority has created a triple helix space for a collaboration for public sector excellence and aspiring private sector competitiveness, but the lack of strong institutional leadership has prevented the generation of sustainable growth, synergies and spill-overs (Lawton Smith and Waters, 2015).

The principal issue in UK economic development is the sharp territorial division between the overperforming South East of the UK economy centred on London, but including its extensive city region, and the underperforming South West and North of England, Wales, Scotland, and Northern Ireland (Regional Policy Commission, 1996; HM Treasury, 2001, 2007; Bailey et al., 2010). Within the individual regional economies there is a similar demarcation of relative performance, such as between core and peripheral and rural and urban areas (Armstrong and Taylor, 2000; Danson and de Souza, 2012). There is a psychological dimension to this as well, as specific regions or communities are not only affected by external changes, but also may respond in different ways: a reflection of confidence and local 
capacity (Cooke, 1985). Taken together, the regional agenda reflects the complexity of modern economies and the intrinsic changes taking place across national economic and industrial spaces (Todeva, 2014).

The relatively differentiated performances over time of the different geographies of the UK are reflected in unemployment, social and community distress, and environmental impacts. Therefore, the challenges for the triple helix action differ across geographies. Although UK government has favoured capital mobility policies, and grants and incentives sought to encourage firms located in the South East to move to the underperforming regions (Armstrong and Taylor, 2000), the regional impact of these policies is very limited (Regional Policy Commission, 1996; Morgan, 2006). It can be argued (Bailey et al, 2010) that the former UK Coalition Government's removal of the region-wide RDAs from their respective landscapes in England undermined further regional strategic approaches to address discrepancies (Danson and Lloyd, 2012). The absence of regional economic partnerships complementing and paralleling the triple helix framework for innovation would be expected to exacerbate this loss (Cooke and Clifton, 2005; Danson et al., 1999).

\section{Conclusions}

RDAs in the UK and across the developed world are very much a product of their times and their specific regional contexts. Economic conditions and expectations, exogenous structural pressures, endogenous capacities, and institutional innovation combine to position RDAs with a broader portfolio of intervention (Danson et al., 2012). These are mediated through prevailing political ideologies regarding state, market and civil relations. The territorial dimensions to these parameters assume considerable importance as the spatial priorities of governments, national and devolved, establish the broad framework within which RDAs operate. The broad debate is over the politics of space: does a political geography of relative economic performance matter? Is there a political geography of competition and competitiveness? Is there evidence of a regional politics of triple helix interactions? How do the principles of regionalism and subsidiarity affect triple helix constellations and economic behaviour within a locale? How do different local governance practices induce a differentiated triple helix context? Are market-led approaches to governance complementary to triple helix and stakeholder approaches, bringing into play critical assumptions about the effectiveness of market penetration across competitive geographies and the effectiveness of stakeholder engagement on localised innovation capabilities. These questions are further disaggregated from national into regional, town and country, urban and rural, city and city-region levels. Yet, any such 'laissez-faire' approach invokes consideration of the deeper social, economic, temporal, resource, and environmental costs of market engineered and government regulated space. 
Regional governance and regional triple helix constellations are the main drivers shaping the politics and economics in a location space. Yet, these operate within their own constraints of national policy regimes, global competition and regulation, and university open door policy for knowledge flows. The principles of regionalism and subsidiarity emphasise that the most appropriate practice level for triple helix interactions is the level which promises the closest impact in terms of value creation and value capture. Regional competitiveness and economic growth, hence, are derivatives to localised triple helix actors and activities.

Within a market-based philosophy which asserts the rationale for the relatively free play of business interests there remains also a powerful case for RDAs to operate at a subnational scale. Even in the context of market conditions, some arrangements for stakeholder engagement and governance are required to address the more localised market failures in land, capital, and labour markets, if only to correct local and regional capacities to respond to changing business and market actions. Uneven economic conditions create territorial costs and disadvantages, and the RDA would appear to be an appropriate model of intervention to provide more coherent spaces for business-based and marketbased activities. The record of Scottish performances in enhancing its key sectors of Food \& Drink (including agriculture \& fisheries), Creative Industries (including digital), Sustainable Tourism, Energy (including renewables), Financial \& Business Services, Life Sciences, and Universities (Scottish Government, 2015) is demonstrated by the very strong growth in the food and drink partnership in recent years (exports up by a third in five years, Scottish Food and Drink, 2014).

The location-based Scottish enterprise areas are focused on four sectors covering 16 sites: Life sciences; Low carbon/renewable; General manufacturing; and Growth sectors and again these have nurtured increased activities (Scottish Enterprise, 2015). The key elements of a triple helix approach are embedded into each of these approaches to regional economic development with the RDAs (Scottish Enterprise and Highlands and Islands Enterprise), universities and private sector companies all active participants, along with other partners. These can be contrasted with the piecemeal, poorly co-ordinated and crowded landscape in England where wasteful pursuit of investment and development by small partnerships in competition with other LEPs (local economic partnerships) struggles to deliver coherent outcomes (Lawton Smith and Waters, 2015; Bailey et al., 2010).

Regional authorities undertake a leadership role in creating institutional space for the functioning of collaborative triple helix interactions, and hold responsibilities for the effective implementation of national policies as well. Effective regional government directly influences the regional effects in national innovation systems, facilitating and enhancing localised stakeholder engagement and collaboration. Governance and intermediation are the tools of regional authorities to promote and position new implementation practices for economic development. Weak regional authorities induce 
weak triple helix constellations, resulting in fragmentation and lack of positive externalities, while active triple helix environments at a regional level generate sustainable growth patterns, as already seen in the literature.

The Scottish Development Agency, for example, as with the equivalent bodies in Wales and Northern Ireland, operated for the first few years under its original remit before being reengineered as a business-led development model (also eventually being renamed as Scottish Enterprise to reflect this changing remit). This process of change to better serve as instruments of business growth and development has continued since and has created vibrant networks across the university-industry interface, embedding the policy implementation and impact into regional spillovers. Hence the RDA in Scotland serves to create greater coherence of the economic, social, environmental, and political space, supporting a localised triple helix constellation. Scottish Enterprise secures economic gains from policy and institutional integrated working, enhancing both the value creation and value capture from triple helix and stakeholder engagement and commitment. Its ability and capacity, however, to fulfil such roles is dependent upon its position in the structure of government and the form and nature of devolution in its specific regional context.

RDAs can mobilise appropriate environmental factors in relation to achieving economic priorities and can operate in the context of localised dynamic conditions reflecting the very complex processes of change taking place in different localities and communities. RDA-led triple helix constellations employ regional or national institutions to implement localised political and economic agendas and to address localised stakeholder demands. Our analysis of the role and impact of institutions, governance and government support on regional capabilities for growth reveals the complementarity between national priorities, regional urge, and the response of the public and private sector to localised policy initiatives. Regional governance and regional triple helix constellations lead the engagement of stakeholders with the national agenda for innovation and entrepreneurship as well as serving their localised needs. It is already recognised that the building blocks of national innovation systems and the regional innovation environments localised around the local university acting as an open door for ideas, creativity, skills and entrepreneurial ambitions, empowered by localised employer activities.

The impact of triple helices on economic growth and sustainable innovation outcomes is best observed at the local / regional scale where industry, university, and other public sector and third sector actors can work effectively with local authorities as is evident, for example, with the emphasis on community planning in local service provision which also incorporates regeneration and social inclusion activities, as well as pursuing innovation and smart specialisation targets. Finally, experience shows that in the wider processes of governance the RDAs can contribute to the strengthening of 
regional and local political capital and institutional capacity to address change and can serve to secure a wider political legitimacy for local interventions to those changes.

This territorial demarcation is accentuated not only by resource availability considerations, inherited industrial and corporate practices, and the priorities of government policy which combine to create a very evident variegated economic spatial landscape. Geographic spaces are made visible and connected to global resource and knowledge flows through their regional triple helix constellations and their localised stakeholder engagement.

The existing geographical inequity is compounded by the uneven capacities of different regional and local communities to address change. Hence, empowering triple helix interface at local, regional, or community level, hence can strengthen the governance function for concerted action and response to policy initiatives. Today, the RDA organisational form continues to represent the basis of regional economic policy and smart specialisation action across much of Europe (Danson, Halkier and Bellini, 2012), and it is paramount that the remaining questions now turn on the more deliberate integration of RDAs into the structure of government and the public policies at large. The RDA model hence offers an opportunity to address macroeconomic challenges across national space whilst seeking greater coherence, consistency, and confidence at the subnational level.

\section{References}

Anselin, L., Varga, A., and Acs, Z. (1997), 'Local geographic spillovers between university research and high technology innovation', Journal of Urban Economics, Vol 42, pp 422-448.

Armstrong, H., and Taylor, J. (2000), Regional Economics and Policy, 3rd edition, Blackwell, Oxford.

Armstrong, H. (1997), 'Regional-level jurisdictions and economic regeneration initiatives', in Danson, M., Lloyd, G., and Hill, S., eds, Regional Governance and Economic Development, Pion, London, pp 26-46.

Asheim, B., Coenen, L., and Svensson-Henning, M. (2003), Nordic SMEs and Regional Innovation Systems, Nordisk Industrifond, Oslo.

Bailey, D., Benneworth, P., Danson, M., and Halkier, H. (2010), The New Local Enterprise Partnerships Memorandum, evidence submitted by the Regional Studies Association to the House of Commons Select Committee on Business, Innovation and Skills, http://www.publications.parliament.uk/pa/cm2010011/cmselect/cmbis/memo/localent/localent 85.htm

Benneworth, P., Lawton Smith, H., and Bagchi-Sen, S. (2015), 'Building inter-organisational synergies in the regional triple helix', Introduction, Industry and Higher Education, Vol 29, No 1, pp 5-10. 
Bergum, S. (2012), 'Proximity and distributed innovations - innovations 'in the shadow of the clusters", in Danson, M., and de Souza, P., eds, Regional Development in Northern Europe: Peripherality, Marginality and Border Issues, Routledge, Abingdon.

Bottazzi, L., and Petri, G. (1997), 'Innovation and spill-over regions: evidence from european patent data, European Economic Review, Vol 47, pp 687-710.

Breschi, S., and Lissoni, F. (2009), Mobility of skilled workers and co-invention networks: an anatomy of localized knowledge flows, Journal of Economic Geography, Vol 9, No 4, pp 439-468.

CEC (Commission of the European Communities) (1994), Growth, Competitiveness Employment: The Challenges and Ways Forward into the 21st Century, Commission of the European Communities, Brussels.

CEC (Commission of the European Communities) (2014), An Introduction to EU Cohesion Policy 2014-2020, available online:

http://ec.europa.eu/regional policy/sources/docgener/informat/basic/basic 2014 en.pdf

CEC (Commission of the European Communities) (2015), Programmes, DG Regio, http://ec.europa.eu/regional policy/en/atlas/programmes/

Cecchini, P. (1988), The European Challenge 1992: The Benefits of a Single European Market, Wildwood House, Aldershot.

Chung, S. (2002), 'Building a national innovation system through regional innovation systems', Technovation, Vol 22, pp 485-491.

Cooke, P, (1985), 'Regional innovation policy: problems and strategies in Britain and France', Environment and Planning C: Government and Policy, Vol 3, pp 253-267.

Cooke P. (2001), Knowledge Economics: Clusters, Learning and Co-operative Advantage, Routledge, London.

Cooke, P., and Morgan, K. (1998), The Associational Economy: Firms, Regions, and Innovation, Oxford University Press, Oxford.

Cooke, P., and Clifton, N. (2005), 'Visionary, precautionary and constrained 'varieties of devolution' in the economic governance of the devolved UK territories', Regional Studies, Vol 39, pp 437-451.

Corder, K. (2009), 'The Federal Reserve System and the credit crisis, Public Administration Review, Vol 69, No 3, pp 623-631.

Danson, M., Fairley, J., Lloyd, G., and Turok, I. (1999), 'The European Structural Fund partnerships in Scotland: new forms of governance for regional development?', Scottish Affairs, Vol 27, pp 23-40. 
Danson, M., Lloyd, G., and Newlands, D. (1990), 'The Scottish Development Agency, economic development and technology policy', in ter Heide, H., ed, Technological Change and Spatial Policy, Nederlandse Geografische Studies, Amsterdam, Vol 112, 179 - 190.

Danson, M., Halkier, H., and Bellini, N. (2012), 'Introduction: rethinking RDAs', in Danson, M., Bellini, N. and Halkier, H., eds, Regional Development Agencies: The Next Generation? Networking, Knowledge and Regional Policies, Regions and Cities, Routledge, Abingdon.

Danson, M., and de Souza, P. eds (2012), Regional Development in Northern Europe: Peripherality, Marginality and Border Issues, Routledge, Abingdon.

Danson, M., and Lloyd, G. (2012), 'Beyond devolution: roads to coherent autonomies?', Environment \& Planning $C$, Vol 30, No 1, pp 78-94.

Deakin, N., and Edwards, J. (1993), The Enterprise Culture and the Inner City, Routledge, London.

Doloreux, D., and Parto, S. (2005), 'Regional innovation systems: Current discourse and unresolved issues', Technology in Society, Vol 27, pp 133-153.

Etzkowitz, H., and Ranga, M. (2010), 'A triple helix system for knowledge-based regional development: from 'spheres' to 'spaces", paper to The Triple Helix VIII International Conference on University, Industry and Government Linkages, Madrid, Spain, available online: http://api.ning.com/files/aBHCyrgWGsw3b1rE26EcQYXOIMMm0k3FFExiR2jWPbP7FUelO*F*Oade 11go9ceXwc4SAttHfBMzYQmSdROH3ISETAEmL*SY/themepaper23Feb1vadjusted.pdf.

Foucault, M. (2008), The Birth of Biopolitics. Lectures at the College de France, 1978-79, Palgrave MacMillan, London.

Frantz, J. (1997), 'The high cost of policy termination', International Journal of Public Administration, Vol 20, No 12, pp 2097-2119.

Giddens, A. (1997), The Third Way: The Renewal of Social Democracy, Policy Press, Oxford.

Gordon, C. (1991), 'Governmental rationality: an introduction', in Burchell, G., Gordon, C., and Miller, P., eds, The Foucault Effect: Studies in Governmentality, University of Chicago Press, Chicago, pp 1-48.

Greenwood, J. (1997), 'The succession of policy termination', International Journal of Public Administration, Vol. 20, No. 12, pp 2121-50.

Halkier, H. (2006), Institutions, Discourse and Regional Development: The Scottish Development Agency and the Politics of Regional Policy, PIE Peter Lang, Brussels.

Halkier, H., and Danson, M. (1997), 'Regional development agencies in Europe: a survey of key characteristics and trends', European Urban and Regional Studies, Vol 4, pp 243-256. 
Harmon, M. (1998), 'Decisionism and action: changing perspectives in organization theory', International Journal of Public Administration, Vol 21, Nos 6-8, pp 819-38.

Hewitt-Dundas, N., and Roper, S. (2011), 'Creating advantage in peripheral regions : the role of publicly funded R\&D centres', Research Policy, Vol 40, pp 832-841.

HM Treasury (2007), Review of Sub-national Economic Development and Regeneration, HM Treasury, Department for Business, Enterprise and Regulations Reform and Department of Communities and Local Government, London.

HM Treasury, BERR, DCLG (2001), Productivity in the UK: The Regional Dimension, HM Treasury, London.

Howells, J. (2005), 'Innovation and regional economic development: A matter of perspective?', Research Policy, 34, pp 1220-1234.

Huggins, R. (2003), 'Creating a UK competitiveness index: regional and local benchmarking', Regional Studies, Vol 37, pp 89-96.

Jeffreys, E., and Sigley, G. (2009), 'Governmentality, governance and China', in Jeffreys, E., ed, China's Governmentalities: Governing Change, Changing Government, Routledge, London, pp 1-23.

Kant, I. (1785), Grounding for Metaphysics of Morals, 2nd ed., Hackett, Indianapolis, IN (translated by J. Ellington).

Keating, M. (2006), 'Nationality, devolution and policy development in the United Kingdom', in Tewdwr-Jones, M. and Allmendinger, P., eds, Territory, Identity and Spatial Planning: Spatial Governance in a Fragmented Nation, Routledge, London, pp $22-34$.

Kerry, C, and Danson, M. (XX) 'Open innovation, triple helix, and regional innovation systems: exploring catapult centres in the United Kingdom', Industry and Higher Education, this volume.

King, D. (1984), Fiscal Tiers: The Economics of Multi Level Government, George Allen and Unwin, London.

Klofsten, M., Bienkowska, D., Laur, I., and Solvell, I. (2015), 'Success factors in cluster initiative management: mapping out the 'Big Five', Industry and Higher Education, Vol 29, No 1, pp 65-77.

Knott, J., and Miller, G. (1987), Reforming Bureaucracy: The Politics of Institutional Choice, PrenticeHall, Englewood Cliffs, NJ.

Koppell, J. (2010), World Rule: Accountability, Legitimacy, and the Design of Global Governance, University of Chicago Press, Chicago. 
Krugman, P. (1991), 'Increasing returns and economic geography', Journal of Political Economy, Vol 99, pp 483-499.

Lawton Smith, H., and Waters, R. (2015), 'Regional synergies in triple helix regions, Industry and Higher Education, Vol 29, No 1, pp 25-35.

Lazzeroni, M., and Piccaluga, A. (2015), 'Beyond 'Town and Gown': the role of the university in small and medium-sized cities, Industry and Higher Education, Vol 29, No 1, pp 11-23.

Lee, C., Bagchi-Sen, S., and Poon, J. (2015), University-industry collaboration in a triple helix settings on a US medical campus', Industry and Higher Education, Vol 29, 1, pp 37-49.

Lemke, T. (2002), 'Foucault, Governmentality and Critique', http://www.andosciasociology.net/resources/Foucault\$2C+Governmentality\$2C+and+Critique+IV-

2.pdf

Lewison, G. (1991), 'The scientific outputs in the EC's less favoured regions,' Scientometrics, Vol 21, pp 383-402.

Lindegaard, K. (2012), 'Dynamics of peripherality', in Danson, M., and de Souza, P., eds, Regional Development in Northern Europe: Peripherality, Marginality and Border Issues, Routledge, Abingdon, pp 78-97.

Lloyd, G. (2008), 'Towards a 'pooled sovereignty' in community planning in Scotland', Local Economy Vol 23, pp 58-68.

Lloyd, G., and Danson, M. (1991), 'The Inverclyde Enterprise Zone: a continuing experiment in regeneration', Scottish Geographical Magazine, Vol 107, pp 58-62.

Morgan, K. (2007), 'The polycentric state: new spaces of empowerment and engagement?', Regional Studies, Vol 41, pp 1237-1251

Morgan, K. (2006), Devolution and development: territorial justice and the north - south divide, Publius: The Journal of Federalism, Vol 36, pp 89-206.

Musgrave, R. (1959), The Theory of Public Finance, McGraw-Hill, New York.

Nauwelaers, C., Perlanez Forte, I., and Midtkandal, I. (2014), 'RIS3 Implementation and Policy Mixes', European Commission, JRC-IPTS, Seville (Spain).

Newlands, D. (1997), 'The economic powers and potential of a devoted Scottish Parliament: lessons from economic theory and European experience', in Danson, M., Lloyd, G., and Hill, S., eds, Regional Governance and Economic Development, Pion, London, pp 109-127. 
Nozawa, K. (2015), 'Regional triple helix, and the contextualisation of regional policy: a comparative analysis of three regions in Japan', Industry and Higher Education, Vol 29, No 1, pp 51-64.

O'Leary, E. (2015), Irish Economic Development: Serial Under-Achievement or High-Performing EU State, Routledge, London.

Regional Policy Commission (1996), Renewing the Regions: Strategies for Regional Economic Development, Sheffield Hallam University, Sheffield.

Russell, G. and Waste, R. (1998), The limits of reinventing government', American Review of Public Administration, Vol 28, No 4, pp 325-346.

Scottish Enterprise (2015), 'Drivers of growth in our business plan 2015-18', http://www.scottishenterprise.com/knowledge-hub/articles/comment/evidence-base-for-our-four-drivers-of-growth

Scotland Food and Drink (2014), 'An export plan for Scotland's food and drink industry', Scotland Food and Drink, Edinburgh.

Scottish Government (2011), Government Economic Strategy, http://www.scotland.gov.uk/Publications/2011/09/13091128/0

Scottish Government (2015), Scotland's Economic Strategy, http://www.gov.scot/Resource/0047/00472389.pdf

Stöhr, W. (1989), 'Local development strategies to meet local crisis', Entrepreneurship and Regional Development, Vol 1, No 3, pp 293-300.

Swyngedouw, E. (1992), 'The Mammon Quest - 'glocalisation', inter-spacial competition, and the monetary order: the new construction of scales', in Dunford, M., and Kafkalas, G., eds, Cities and Regions in the new Europe: The Global Local Interplay and Spatial Development Strategies, Belhaven Press, London, pp 39-68.

Syrett, S. (2011), 'Conceptualising marginalisation in cities and regions", in Peripherality, Marginality and Border Issues in Danson, M., and de Souza, P., eds, Regional Development in Northern Europe: Peripherality, Marginality and Border Issues, Routledge, Abingdon, pp 65-77.

Tewdwr Jones, M., and Phelps, N. (2000), 'Levelling the uneven playing field: inward investment, interregional rivalry and the planning system', Regional Studies, Vol 34, pp 429-440.

Todeva, E. (2010), 'Theoretical tensions between regulation, governance, and strategic behaviour in a federated world order', International Journal of Social Economics, Vol 37 No 10, pp 784-801.

Todeva, E. (2013), 'Governance of innovation and intermediation in the triple helix interactions', Industry and Higher Education, Vol 27, No 4, pp 263-278. 
Todeva, E. (2014), 'Market driven clusters as prerequisites and consequences of smart specialisation', Journal of the Knowledge Economy, Vol 6, No 2, pp 25-269. DOI 10.1007/s13132-014-0221-8.

Todtling, F., and Kaufmann, A. (2001), 'The role of the region for innovation activities of SMEs', European Urban and Regional Studies, Vol 8, No 3, pp 203-15.

Wamsley, G. (1990), 'Introduction', in Wamsley, G., Bacher, R., Goodsell, C., Kronenberg, P., Rohr, J., Stivers, C., White, O., and Wolf, J., eds, Refounding Public Administration, Sage, Newbury Park, CA, pp 1-5. 